\title{
MYCORRHIZAL DIVERSITY OF AN ENDEMIC TERRESTRIAL ORCHID
}

\author{
Jyotsna Sharma ${ }^{1,3}$, Maria L. Ishida ${ }^{1} \&$ Vernal L. Yadon ${ }^{2}$ \\ ${ }^{1}$ University of Florida, 155 Research Road, Quincy, Florida, 32351, USA \\ ${ }^{2}$ Pacific Grove Museum of Natural History, 165 Forest Avenue, Pacific Grove, California, 93950, USA \\ ${ }^{3}$ Author for correspondence: jyotsna@ufl.edu
}

Key Words: Ascomycetes, Basidiomycetes, Pinus radiata, Arctostaphylos, Piperia yadonii

\begin{abstract}
Mycorrhizal associations of the Orchidaceae - the largest and most diverse angiosperm family with an estimated number of taxa ranging between 17,000 and 35,000 - are highly complex. Plant-fungus interactions in this family can range from obligate- or fac-
\end{abstract} ultative mycotrophy, mutualism, to minimal dependence on fungi in adulthood (Smith \& Read 1997, Sivasithamparam et al. 2002, Taylor et al. 2002, Cameron et al. 2006). Terrestrial orchids also generally exhibit high habitat specificity. A unique ecological reliance upon mycorrhizal fungi is one of the reasons for habitat specificity in orchids. The fungal association is especially critical during the seed germination phase, but continues through the life-cycle of the plants, especially in the obligate mycotrophic species. It can therefore be expected that recruitment and persistence of orchids in their natural habitat depends on the availability of suitable fungi, which also form an underground network that connects orchids with the surrounding vegetation. Fungal ecology often is overlooked in orchid conservation projects, but if orchid-fungus relationships are very specific, the persistence of a population and/or success of a reintroduction program will be affected greatly by the presence or absence of suitable fungi in the soil, and by the habitat's ability to continuously support these fungi.

Piperia yadonii R. Morgan \& J. Ackerman (a photosynthetic terrestrial) is endemic to Monterey County in California and is listed endangered by the US Fish and Wildlife Service. The Monterey area is part of the California Floristic Province Biodiversity Hotspot and represents the northern or southern limit of natural distribution of many plants, several of which co-occur with this orchid. Piperia yadonii occurs in two distinct habitats within its natural range: 1) lower elevation Pinus radiata D. Don forests with an herbaceous, sparse understory; and 2) higher elevation ridges in maritime chaparral growing beneath dwarfed Arctostaphylos hookeri G. Don shrubs. Biodiversity Hotspots are characterized both by exceptional levels of plant endemism and by dangerous levels of habitat loss. Only a few extant populations of $P$. yadonii remain and/or are known, and these are seriously threatened because of the increasing pressure from urban and recreational development in the area. One of the goals of USFWS is to downlist the species as threatened instead of delisting, primarily because its biology is not yet well enough understood to set delisting as an objective of the Recovery Plan (U.S. Fish and Wildlife Service 2004). Prior to this work, mycobionts of $P$. yadonii have not been studied. The specific objectives of this research were to: (1) identify fungal diversity associated with $P$. yadonii at selected sites/populations along two, a longitudinal and a latitudinal, transects across its natural distribution, and (2) identify how the fungal diversity of the orchid is related to both habitat types, and to the size of the orchid populations.

\section{Materials and Methods}

Roots of Piperia yadonii were collected between February and March of 2005 and 2006 from several locations across its natural distribution. Soil samples also were collected from each site to determine the soil chemical properties at each location. All materials were transported at $4^{\mathrm{O}} \mathrm{C}$ to the laboratory. Root sections were processed by using culture dependent and culture independent methods to assess the identity and diversity of the culturable and non-culturable mycobionts of $P$. yadonii. To obtain pure cultures of the peloton-forming fungi, we slightly modified the 
method described in Sharma et al. (2003). When pure cultures of fungal isolates were obtained, DNA was extracted from these isolates. Fungal internal transcribed spacer (ITS-1) region then was amplified by using the primer pair ITS-1F/ITS-4 (Gardes \& Bruns 1993). Digestion with restriction enzymes was used to obtain restriction fragment length polymorphism (RFLP) data. Based on the RFLP data, we subsequently selected isolates with unique profiles and subjected these to sequencing by using T7 and SP6 primers. For identifying the fungi by using culture independent method, thin sections of roots first were examined under the microscope to locate regions which contained fungal pelotons. We then extracted total DNA from these sections. In this case also, we amplified the fungal ITS-1 region by using the same primer pair as above, but followed with cloning the product. Clones were digested with EcoRV before selecting the unique profiles and subjecting these selected clones to sequencing with the same primers as above. In both cases, only those sequences whose T7 and SP6 (reverse complement) sequences matched completely were used further. Similar sequences were searched by using BLAST program (Altschul et al. 1997) by accessing the NCBI web-page (http://www.ncbi.nlm.nih.gov/blast/Blast.cgi). We used the default settings to conduct these searches.

\section{Results and Discussion}

Preliminary results show that fungi associated with Piperia yadonii primarily belong to the taxonomic groups Ascomycetes and Basidiomycetes, some of which have previously been reported as ectomycorrhizae of coniferous trees (Table 1). While some of the fungi identified thus far in our work have been reported from temperate terrestrial orchids, photosynthetic and non-photosynthetic, many have not previously been reported as orchid endophytes. Other fungi belonged to Phomopsis (Ascomycota), Ceratobasidium (Basidiomycota), Neonectria (Ascomycota), and Phialocephala (Ascomycota), which are reported to be coniferous ectomycorrhizae. Ceratobasidium spp., which are known to associate with many terrestrial orchids worldwide (Zettler et al. 2003), occurred at several sites including both Pinus radiata and Arctostaphylos spp. dominated habitats.
Insofar, few individual species or taxonomic groups of fungi were observed at locations excepting MC (Table 1). This is a site which is close to urban areas and harbors a very small population of the orchid. On the other hand, the other sites, including those which harbor large numbers of orchids and/or are more isolated, yielded a low diversity of fungi associated with these plants. Because we are now using additional primers to amplify (in order to identify fungi unidentified this far) the fungal ITS-1 region of the same DNA samples, our forthcoming results may reveal a different pattern of fungal diversity in these locations.

While conserving plant diversity in biodiverse habitats is recognized as an outstanding global priority, there has been limited recognition of the macro level conservation in relation to ecosystem functioning at the micro level (Sivasithamparam et al. 2002). This is a result of a lack of knowledge and understanding of the micro level communities. Our results presented herein indicate that Ascomycetes, especially those forming ectomycorrhizae with the surrounding vegetation, may be equally critical to the persistence of this orchid as might be the saprophytic fungi or the Basidiomycetes from the Rhizoctonia complex, which are generally believed to be the primary orchid endophytes.

\section{Literature Cited}

Altschul, S.F., T.L. Madden, A.A. Schäffer, J. Zhang, Z. Zhang, W. Miller \& D.J. Lipman. 1997. Gapped BLAST and PSI-BLAST: a new generation of protein database search programs. Nucleic Acids Res. 25: 3389-3402.

Cameron, D.D., J.R. Leake \& D.J. Read. 2006. Mutualistic mycorrhiza in orchids: evidence from plant-fungus carbon and nitrogen transfers in the green-leaved terrestrial orchid Goodyera repens. New Phytol. 171: 405-416.

Carter, J.P., J. Spink, P.F. Cannon, M.J. Daniels \& A.E. Osbourn. 1999. Isolation, characterization, and avenacin sensitivity of a diverse collection of cereal-root-colonizing fungi. Appl. Environ. Microbiol. 65(8): 3364-3372.

Gardes, M. \& T.D. Bruns. 1993. ITS primers with enhanced specificity for basidiomycetes: application to the identification of mycorrhizae and rusts. Mol. Ecol. 2: 113-118.

Julou, T., B. Burghardt, G. Gebauer, D. Berveiller, C. Damesin \& M.A. Selosse. 2005. Mixotrophy in orchids: insights from a comparative study of green individuals and nonphotosynthetic individuals of Cephalanthera damasonium. New Phytol. 166 (2): 639-653.

Menkis, A., J. Allmer, R. Vasiliauskas, V. Lygis, J. Stenlid \& R. Finlay. 2004. Ecology and molecular characterization of 
TABLE 1. Fungal ITS-1 region of the mycobionts associated with roots of Piperia yadonii, an endemic terrestrial species, was sequenced and matched with previously known, similar sequences by using the BLAST program (Altschul et al. 1997) by using the NCBI web-page (http://www.ncbi.nlm.nih.gov/blast/Blast.cgi).

\begin{tabular}{|c|c|c|c|}
\hline Previously Listed Source/Host & $\begin{array}{l}\text { Closest sequence(s) found } \\
\text { in GenBank by BLAST }\end{array}$ & Taxonomic Classification & Reference \\
\hline $\begin{array}{l}\mathbf{M C}^{\mathbf{Z}} \\
\text { Pine O-horizon soil }\end{array}$ & Uncultured ascomycete & Eukaryota; Fungi; Ascomycota & O’Brian et al. 2005 \\
\hline Picea abies decayed root & Phomopsis columnaris & Eukaryota; Fungi; Ascomycota & Menkis et al. 2006 \\
\hline Isolated from roots of Triticum $\mathrm{sp.}$ & Phomopsis sp. & Eukaryota; Fungi; Ascomycota & Carter et al. 1999 \\
\hline $\begin{array}{l}\text { Mycorrhizal root tips (host } \\
\text { Cephalanthera damasonium) }\end{array}$ & $\begin{array}{l}\text { Uncultured mycorrhizal } \\
\text { ascomycete }\end{array}$ & Eukaryota; Fungi; Ascomycota & Julou et al. 2005 \\
\hline $\begin{array}{l}\text { Cultured fungus from mycorrhizal } \\
\text { hemlock root tip }\end{array}$ & Phialocephala fortinii & Eukaryota; Fungi; Ascomycota & Lim et al. unpubl. data \\
\hline $\begin{array}{l}\text { Tricholoma matsutake fairy rings } \\
\text { in a natural Pinus densiflora forest }\end{array}$ & $\begin{array}{l}\text { Uncultured ectomycorrhizal } \\
\text { fungus }\end{array}$ & Eukaryota; Fungi & $\begin{array}{l}\text { Lian et al. } 2005 \text { (published } \\
\text { only in NCBI database) }\end{array}$ \\
\hline $\begin{array}{l}\text { Natural Tuber magnatum truffle- } \\
\text { ground }\end{array}$ & Uncultured Nectriaceae & Eukaryota; Fungi; Ascomycota & Murat et al. 2005. \\
\hline Pinus sylvestris decayed root & Neonectria macrodidyma & Eukaryota; Fungi; Ascomycota & Menkis et al. 2006 \\
\hline $\begin{array}{l}\text { BC } \\
\text { Picea abies wood disc }\end{array}$ & Ceratobasidium sp. & Eukaryota; Fungi; Basidiomycota. & Menkis et al. 2004 \\
\hline $\begin{array}{l}\text { PQR } \\
\text { Environmental sample }\end{array}$ & Uncultured ectomycorrhiza & Eukaryota; Fungi; Basidiomycota & Murat et al. 2005 \\
\hline $\begin{array}{l}\text { SFB } \\
\text { Picea abies wood disc }\end{array}$ & Ceratobasidium $\mathrm{sp}$ & Eukaryota; Fungi; Basidiomycota & Menkis et al. 2004 \\
\hline $\begin{array}{l}\text { PL } \\
\text { Taxus chinensis var. mairei }\end{array}$ & Fungal endophyte & Eukaryota; Fungi; Ascomycota & $\begin{array}{l}\text { Wang \& Wang } \\
\text { Unpublished }\end{array}$ \\
\hline Not listed & Cercophora sparsa voucher & Eukaryota; Fungi; Ascomycota & Miller \& Huhndorf 2004 \\
\hline $\begin{array}{l}\text { JP } \\
\text { Soil }\end{array}$ & Uncultured soil fungus & Eukaryota; Fungi & Waldrop et al. unpubl. data \\
\hline $\begin{array}{l}\text { MP } \\
\text { Picea abies wood disc }\end{array}$ & Ceratobasidium sp. & Eukaryota; Fungi; Basidiomycota & Menkis et al. 2004 \\
\hline
\end{tabular}

$\mathrm{z}_{\mathrm{MC}}, \mathrm{BC}, \mathrm{PQR}, \mathrm{SFB}, \mathrm{PL}, \mathrm{JP}$, and MP are codes for locations from which roots of Piperia yadonii were collected.

dark septate fungi from roots, living stems, coarse and fine woody debris. Mycol. Res. 108: 965-973.

Menkis, A., R. Vasiliauskas, A.F.S. Taylor, E. Stenstrom, J. Stenlid \& R. Finlay. 2006. Fungi in decayed roots of conifer seedlings in forest nurseries, afforested clear-cuts and abandoned farmland. Plant Pathol. 55(1): 117-129.

Miller, A.N. \& S.M. Huhndorf. 2004. Using phylogenetic species recognition to delimit species boundaries within Lasiosphaeria. Mycologia 96(5): 1106-1127.

Murat, C., A. Vizzini, P. Bonfante \& A. Mello. 2005. Morphological and molecular typing of the below-ground fungal community in a natural Tuber magnatum truffleground. FEMS Microbiol. Lett. 245(2): 307-313.

O’Brien H.E., J.L. Parrent, J.A. Jackson, J.M. Moncalvo \& R. Vilgalys. 2005. Fungal community analysis by large-scale sequencing of environmental samples. Appl. Environ. Microbiol. 71(9): 5544-5550.

Sharma, J., L.W. Zettler \& J.W. Van Sambeek. 2003. A survey of mycobionts of federally threatened Platanthera praeclara (Orchidaceae). Symbiosis 34: 145-155.

Sivasithamparam, K., K.W. Dixon \& R.L. Barrett. 2002. Microorganisms in plant conservation and biodiversity. Pp. 
195-226. Kluwer, Dordrecht, The Netherlands.

Smith, S.E. \& D.J. Read. 1997. Mycorrhizal symbiosis. Academic Press, New York, NY, USA.

Taylor D.L., T.D. Bruns, J.R. Leake \& D.J. Read. 2002. Mycorrhizal specificity and function in myco-heterotrophic plants. Pp 375-414 in: R. Sanders, I.R. \& M. van der Heijden (eds.). The ecology of mycorrhizas. Ecological Studies vol. 157. Springer-Verlag, Berlin, Germany.
U.S. Fish and Wildlife Service. 2004. Recovery Plan for Five Plants from Monterey County, California. U.S. Fish and Wildlife Service, Portland, Oregon. Xii+ 159 pp.

Zettler, L.W., J. Sharma \& F.N. Rasmussen. 2003. Mycorrhizal Diversity. Pp. 205-226 in: Dixon, K.W., S.P. Kell, R.L. Barrett \& P.J. Cribb (eds.). Orchid conservation. Natural History Publications, Kota Kinabalu, Sabah, Malaysia.

Jyotsna Sharma received her Ph.D. in Plant Science at the University of Missouri-Columbia, USA. She is currently an Assistant Professor in the Department of Environmental Horticulture and an affiliate in the School of Natural Resources and Environment at the University of Florida NFREC. Her research focuses on the study of rhizosphere microbes for applications in environmental remediation and conservation. She also is the Editor of the Native Orchid Conference Journal, which is a quarterly publication of the Native Orchid Conference, Inc., USA.

Maria L. Ishida has technical expertise in microbiology, biochemistry, and molecular biology. She earned her Ph.D. in Biochemistry at the Federal University of Parana, Brazil, and currently is a Biological Scientist for the rhizosphere microbiology program in the Department of Environmental Horticulture at University of Florida NFREC.

Vernal L. Yadon is a botanist (Piperia yadonii is named after him) and Director Emeritus of the Pacific Grove Museum of Natural History where he served for 35 years. He received an M.S. from Oregon State University, Corvallis, Oregon, USA, in Fish and Game Management. He currently serves as a consultant to the review committee that passes on proposed changes for The Inventory of Rare and Endangered Plants of California. His research continues to be a database of vouchers of Monterey County plants. He has authored a Revision of the Vascular Plants of Monterey County, California, in press. 